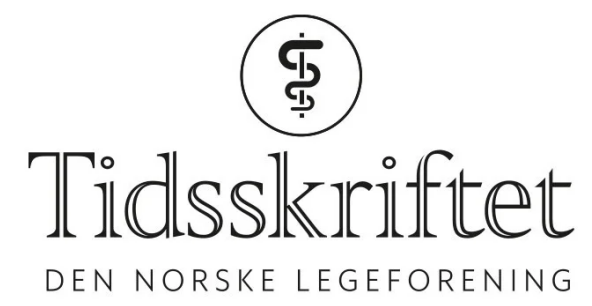

\title{
Stødig på glattisen
}

INTERVJU

MARIT TVEITO

marit.tveito@aldringoghelse.no

Nasjonal kompetansetjeneste for aldring og helse

Hun vokste opp i en ishall og har vært norgesmester i kunstløp tre ganger. Mye trening på glatt is kan ha bidratt til at anestesilegen klarer å sjonglere nasjonale verv i idretten med håndtering av korona på den intensivavdelingen som fikk flest covid-19-pasienter. 


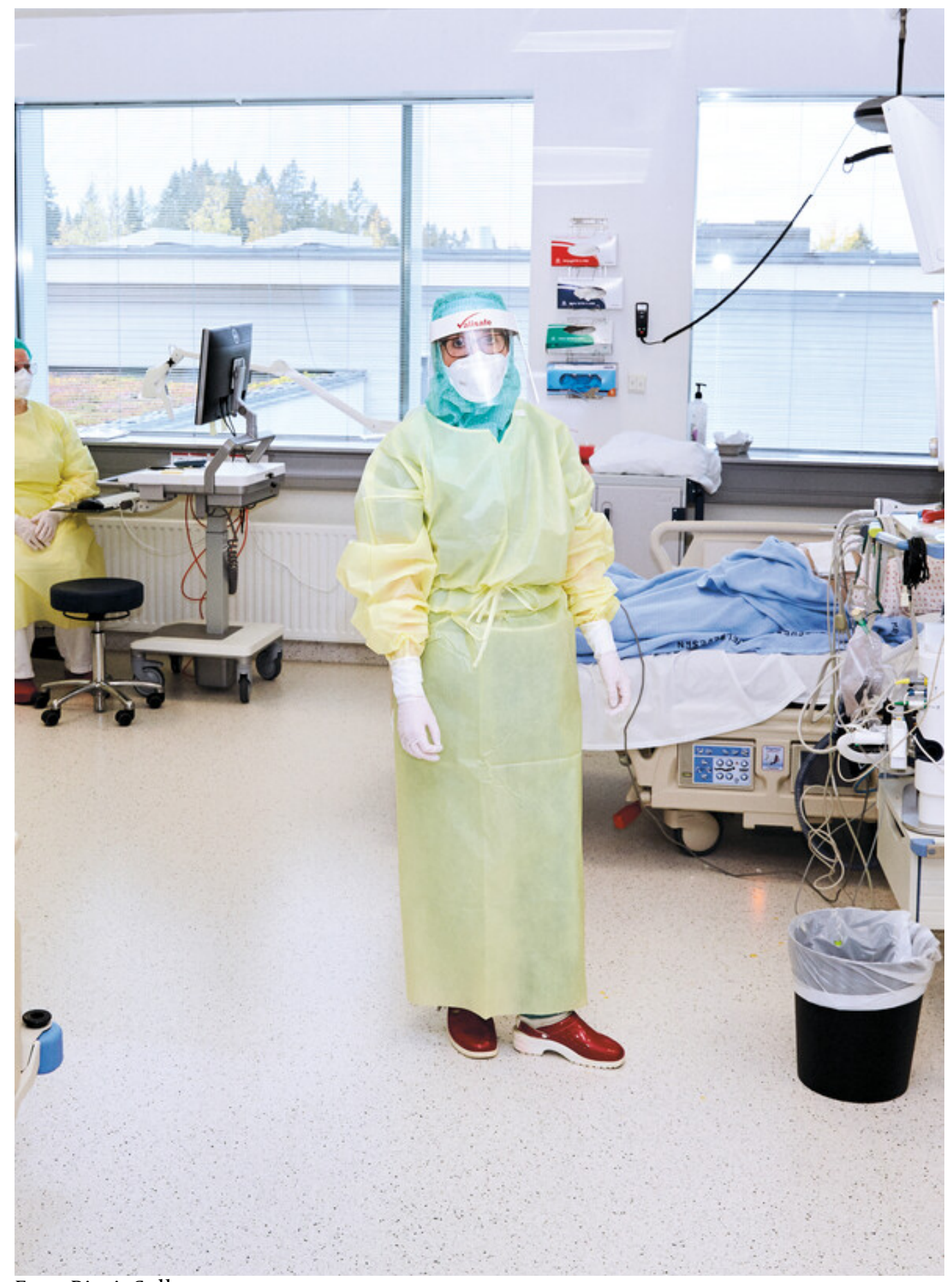

Foto: Birgit Solhaug

Man blir vant til det etter hvert. Kø med god avstand utenfor hovedinngangen til sykehuset. Sjekkliste og vakter.

«Bare ring når du er der», hadde Vibecke Sørensen sagt. Hun melder kjapt og kort i telefonen at hun kommer.

Hun har rask gange, grønne klær og røde tresko som matcher håret. Vi tar trappene, skal helst ikke bruke heisen av hensyn til smitte, og går inn på en tilsynelatende rolig intensivavdeling på Akershus universitetssykehus, avdelingen som fikk flest koronasyke pasienter innlagt da pandemien bølget innover landet. Vi setter oss med god avstand til hverandre på et stort møterom for pårørende.

- Jeg glemte å si at jeg har vakt, sier hun.

- Det går sikkert bra, vi er jo rett i nærheten hvis det skjer noe. 
Ingen alarmer piper, og det er vanskelig å se for seg at rommet for kort tid siden var provisorisk kontor for anestesileger som stod overfor en ny sykdom med et ukjent antall pasienter i vente. Sørensen, som er seksjonsoverlege ved Intensivavdelingen, fikk en viktig rolle da hele sykehuset måtte legge om driften. Kollegene omtaler henne som en nøkkelperson for håndteringen av koronasyke. Noen mener det rett og slett ikke ville ha gått like bra uten henne. Kombinasjonen av mange års erfaring som idrettsutøver på høyt nivå med akuttmedisin og organisasjonserfaring har nok bidratt til at hun er flink til å lykkes med å gjøre mange ting på en gang.

\section{Kunstløp og folkehelse}

At det var lege Sørensen skulle bli, lå ikke i kortene. Hun tilbrakte store deler av barndommen i ishaller, ble norgesmester i kunstløp tre ganger og har deltatt i både EM og VM.

\section{Vibecke Sørensen}

Født 15. oktober 1968

Cand.med., Universitetet i Bergen 1998

Kommunelege i Havøysund 2000

Spesialist i anestesiologi 2010

Seksjonsoverlege, Intensivavdelingen, Akershus universitetssykehus fra 2018

Norgesmester i kunstløp i 1982, 1984, 1985

Styremedlem i Norges Skøyteforbund 2002-08

President i Norges Skøyteforbund 2008-13

Styremedlem Antidoping Norge 2014-15

Styremedlem Idrettsstyret 2015-19

1. visepresident i Idrettsstyret 2019-23

\section{- Hvorfor kunstløp?}

Både moren og tanten min drev med kunstløp, så jeg fikk tidlig prøve meg. Jeg drev med mye, også turn, friidrett og ballett, men det var kunstløp som var mest gøy.

- Faren min er fra Grünerløkka og moren min fra Kampen, like ved Jordal Amfi, et knutepunkt for kunstløpmiljøet.

Ishallen ble et viktig tilholdssted for Sørensen.

- Du ble juniormester bare tolv år gammel?

- Jeg var med på landslaget fra jeg var ni år gammel. Det ble tidlig mye trening.

- Det var kanskje greit på den tiden?

- Det var ikke så mye fokus på uheldige konsekvenser av for mye trening i ung alder, og barneidrettsbestemmelsene var ikke satt i system da. Jeg trente nok opptil seks ganger i uken fra ni års alder, men jeg trente variert og var veldig lite plaget med skader.

- Hva tenker du om det nå?

- Trening var min form for lek. Selv om det også ble konkurranser tidlig, var det bare en del av opplegget. For meg var det lystbetont.

- Noen er bekymret for at barn blir spesialisert for tidlig i idrett? 
- Spesialisering og ensidig trening er to forskjellige ting. Man kan velge en idrett tidlig, men allikevel trene allsidig.

Venner og kolleger forteller at hun særlig brenner for barneidretten.

- Du har vært bekymret for at økonomien bremser deltakelsen for barn?

- Det er økonomisk barrierer for å delta i idrett i Norge. Det jobber vi i Norges

idrettsforbund med, også politisk. Vi ønsker å inkludere alle. Idretten er et viktig fellesskap og bidrar til god folkehelse.

- Tenker du på folkehelsen når du sitter i idrettsstyret?

- Det gjør jeg. Samtidig er idrettens hovedmål å sørge for aktivitet - ikke primært folkehelse, men det er en viktig sekundærgevinst. Jeg ser at det hadde vært gunstig med enda nærere samarbeid mellom medisinen og idretten.

\section{Nordover}

Sørensen ble lege mest fordi det virket spennende å lære mer om kroppen. Idretten hadde vekket interessen for anatomi og fysiologi. Etter å ha studert i Bergen, hvor hun også var kunstløpstrener for barn og jobbet ved legevakten, gikk ferden langt nordover.

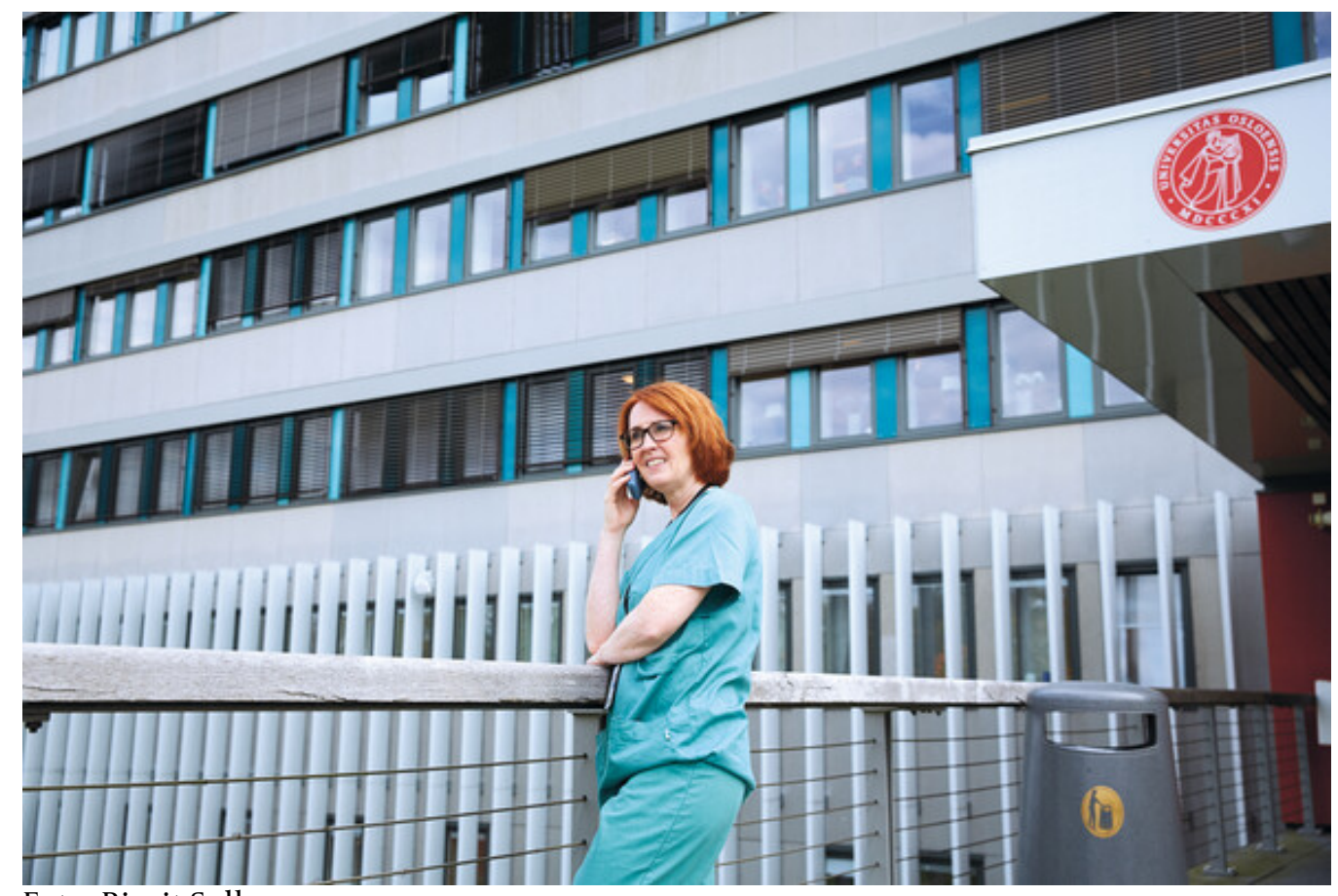

Foto: Birgit Solhaug

- Jeg fikk ikke det beste nummeret i turnustrekningen, kommenterer hun tørt. Men jeg så på det som en mulighet. Først ble det sykehustjeneste i Hammerfest, og så distriktstjeneste i Havøysund. Det var lærerikt.

Callingen ringer.

- Vibecke, intensiv.

Hun svarer kort, konsist og har åpenbart god oversikt over en pasient som kom til avdelingen bare for noen timer siden.

«En kollega sa i etterkant at det å gå inn til den første pasienten med covid-19 føltes som å skulle hoppe i fallskjerm»

- Hvor var vi? 
- I Havøysund.

- Ja, det var andre forhold enn her. Det var 25 mil til sykehus, og veien var ofte stengt. Hvis det skjedde noe akutt, måtte kanskje rutebåten brukes og passasjerene vente. Jeg trivdes, og endte opp med å bli lenger enn nødvendig.

Etter hvert ble det jobb ved Legevakten i Oslo før hun kom til Anestesiavdelingen ved Aker sykehus.

- Jeg hadde noen fine og lærerike år på Legevakten, men etter hvert bestemte jeg meg for spesialisering i anestesi. Det er et valg jeg er veldig fornøyd med.

\section{Koronatid}

Som anestesilege på en intensivavdeling var Sørensen midt i stormens øye da koronaviruset nådde landet.

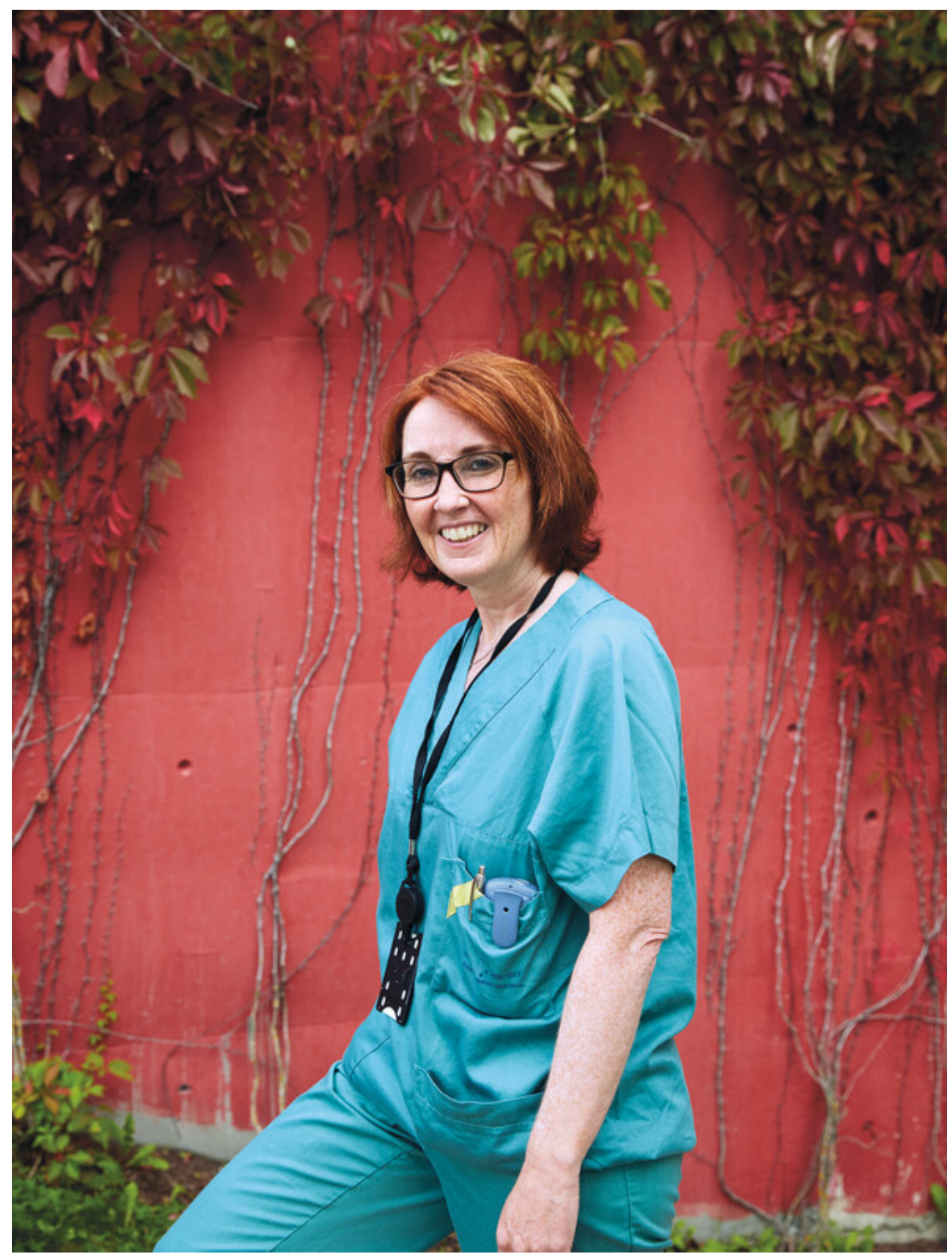

Foto: Birgit Solhaug 
- Rakk dere å forberede dere?

- Vi fulgte med på utviklingen i Kina og Italia, men det tok litt tid før vi tok innover oss at dette kom til å komme til vårt sykehus også. Det gikk litt fortere enn vi trodde, så i starten jobbet vi parallelt med behandling og planlegging. Det har aldri blitt gjort så store endringer på avdelingen så raskt før. Det var fint å se hvor godt vi kan samarbeide når det virkelig gjelder.

- Hva imponerte deg mest?

- Arbeidsinnsatsen og moralen til alle kollegene, lagfølelsen vi fikk og vissheten om at vi hjelper hverandre, selv om mange også var redde i begynnelsen. En kollega sa i etterkant at det å gå inn til den første pasienten med covid-19 føltes som å skulle hoppe i fallskjerm. Vi hadde hørt og lest om pasientene som døde, og vi hørte om helsepersonell som ble alvorlig syke og døde. Med mer erfaring ser vi jo at de ikke er så annerledes enn pasientene vi er vant til.

- Tror du det blir «normalt» igjen på sykehusene?

- Nå er det ganske normalt, men vi går hele tiden med koronaviruset i tankene, og det kommer vi til å leve med lenge. Vi kan ikke senke skuldrene, men må hele tiden være nøye med smittevern og følge med på utviklingen. Den dagen du tror at du vinner alle kampene fordi det går greit, så taper du.

- Hvordan var det å skulle stå i front med vissheten om at det var knapphet på smittevernutstyr?

- Det var en spesiell stemning på avdelingen. Det ble utarbeidet kriterier for bruk av masker og munnbind. Det var rasjonering, og ikke alle som ønsket og mente de skulle ha, kunne få utdelt masker til enhver tid. I starten skulle vi også resirkulere maskene, og de hang rundt til tørk. Det likte jeg ikke. At pasientene var både yngre og friskere i utgangspunktet enn vi hadde trodd, og vi i tillegg var usikre på vår egen beskyttelse, var belastende for mange.

«Den dagen du tror at du vinner alle kampene fordi det går greit, så taper du»

- Dere har hatt lav dødelighet blant innlagte covid-19-pasienter?

- Blant intensivpasienter som har vært på respirator, har vi hatt lav dødelighet sammenlignet med mange andre land, bare $10 \%$. Frem til august hadde vi hatt over 40 pasienter på respirator. Det har vært motiverende med gode behandlingsresultater, og det gir oss tro på at vi gjør en god og riktig jobb. Alle har bidratt, også avdelingene rundt har tatt ekstra pasienter og har fått arbeidsoppgaver som de ikke pleier å ha. Det har vært ressurskrevende, og jeg håper vi klarer å fortsette den gode innsatsen og det gode samarbeidet ved en eventuell ny bølge. Det blir avgjørende med godt lederskap og kloke beslutninger også fremover.

- Har du vært redd for å bli syk selv?

- Nei, det er jeg ikke redd for. Jeg er mer redd for ikke å ha bidratt godt nok til at systemet fungerer, og at andre blir smittet.

\section{Forut for me too}

For mange er det en litt fjern avissak, men som president i Norges Skøyteforbund måtte Sørensen håndtere en sak om en trener som kanskje ville havnet i kategorien me too hvis den hadde oppstått i dag. 


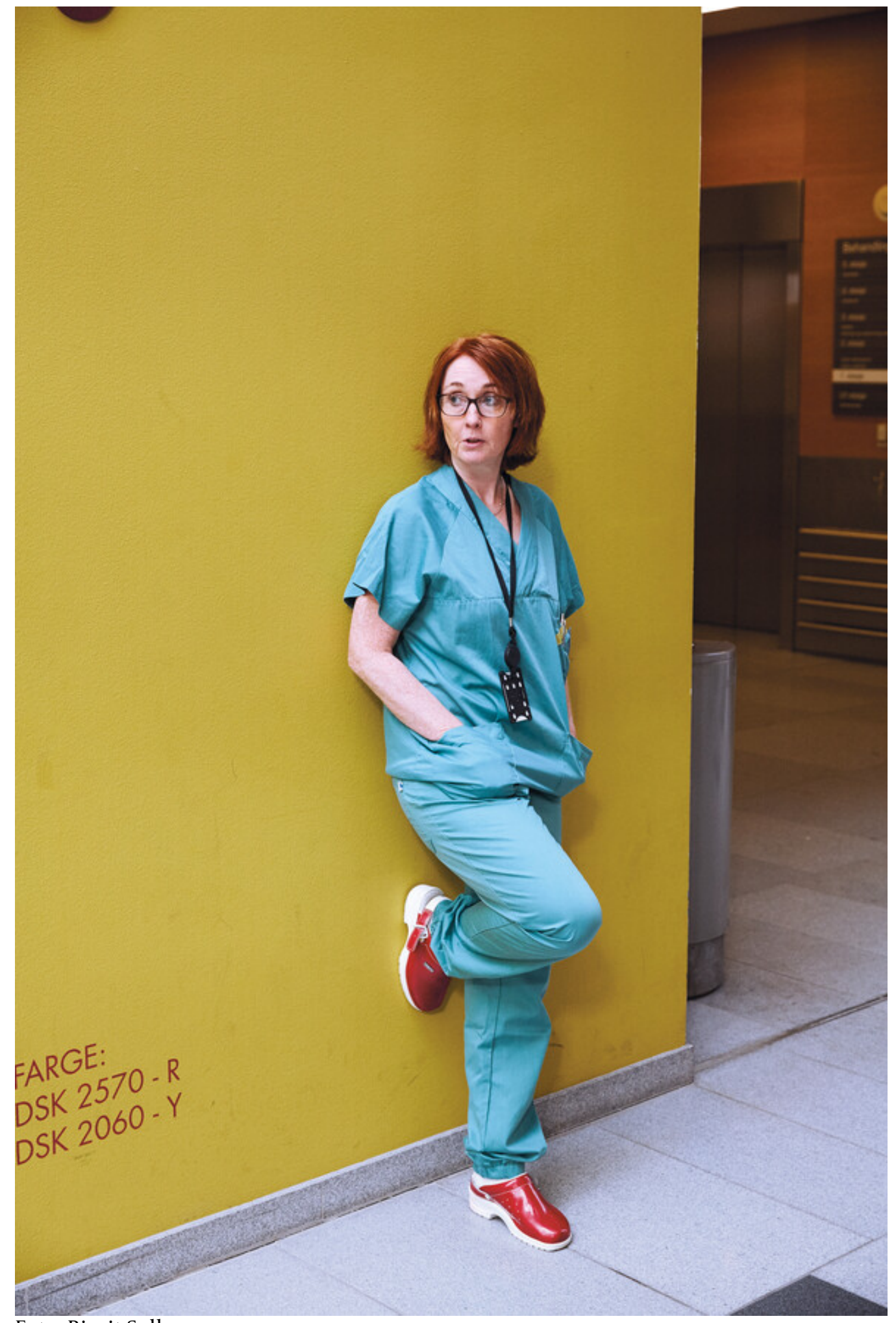

Foto: Birgit Solhaug

- Du tenker på Peter Mueller-saken? Det begynner å bli lenge siden, det var like før OL i Vancouver i 2010.

- Har du reflektert over dette i etterkant, når du ser hvordan samfunnet har utviklet seg?

- Det var en krevende sak, og det ville den nok ha vært uansett når den kom.

- Hvordan var det å være leder i en slik situasjon?

- Jeg hadde nok nytte av erfaringen som lege. Vi er drillet i utredning, beslutning og konsekvens. Dessuten hadde vi et godt og samkjørt styre. Beslutningen vi kom frem til, måtte vi fronte og stå for - det at skøyteløpernes landslagstrener måtte slutte. Det var en tøff sak, både for enkeltpersoner og for hele forbundet. Vi skulle alle vært den saken 
foruten. Hvis den saken hadde skjedd etter me too-kampanjen, hadde det nok vært større forståelse for vår avgjørelse. Jeg fikk sinte e-poster fra fremmede mennesker, der jeg ble rådet til å rømme landet. Det tror jeg kanskje ikke man hadde fått nå. Jeg måtte isolere meg fra å lese alt, jeg har sikkert ikke lest alt ennå.

\section{"Jeg kan ikke bare ta med meg inntrykkene fra en stor intensivavdeling $i$ unntakstilstand og si: Nå stopper vi med idrett, dere»}

- Det var mange leserbrev i saken.

- Det var det nok, men jeg ble god til å koble av. Det var slitsomt på den måten at det var mange aktører, og det varte lenge, men jeg er fortsatt bestemt på at det var en riktig beslutning.

- Du får ikke truende e-poster lenger?

- Nei, men det er stadig noen som kommer bort og spør meg om det virkelig var riktig at samarbeidet med Peter Mueller ble avsluttet.

\section{Styre og stell}

- Hvorfor engasjerte du deg i idrettens organisasjonsliv?

- Idretten har alltid vært en viktig del av livet mitt. Jeg tenkte at jeg kunne bidra med å være med i styret til Skøyteforbundet, men jeg ble raskt et ganske operativt styremedlem. I begynnelsen jobbet jeg spesielt for kunstløp og var toppidrettsansvarlig for den gruppen. Jeg syntes det var veldig gøy å jobbe tett med utøverne, og det var stort da vi nådde målet med å få med en kunstløper til OL i Sotsji i 2014. Det var vår første kunstløper i OL siden 1964. Etter hvert ble jeg president i Skøyteforbundet og har etter flere år i idretten med ulike roller og verv fått mye erfaring og kompetanse fra organisasjonen. Når man blir valgt inn i idrettsstyret, er det først og fremst kunnskap og erfaring man kan bidra med. Idrettsforbundet er Norges største frivillige bevegelse, og beslutningene påvirker mange. Åpenhetsdebatten var krevende, synes jeg. Jeg ønsker først og fremst å bidra til å tilrettelegge for at flest mulig kan delta i idrett og aktivitet. Noen beslutninger er imidlertid samfunnspolitiske, og da er det viktig at idretten er politisk fargeblind. Partipolitikk må aldri komme i veien for det som er en god sak for idretten.

- Idretten har lidd under koronaen, hva tenker du om det? 


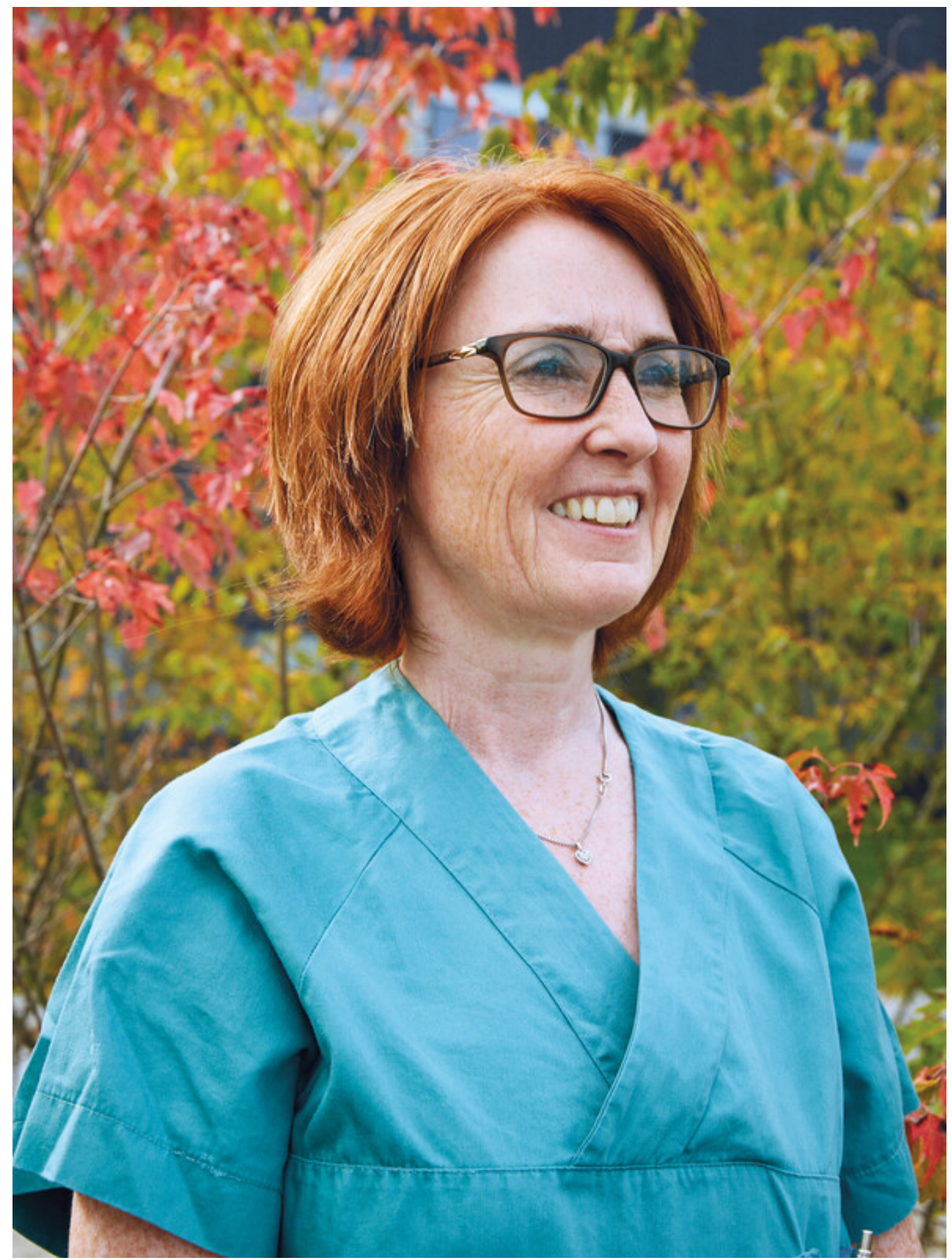

Foto: Birgit Solhaug

- Det er to veldig ulike roller å være på jobb i en intensivavdeling og 1. visepresident $\mathrm{i}$ idrettsstyret. Det har tidvis vært krevende. Jeg ønsker jo å bidra til mest mulig idrettsaktivitet, samtidig som man i idretten kan bli for ivrig etter å komme i gang. Det kan være vanskelig å forstå begrensningene når man ikke ser konsekvensene på nært hold. Jeg har prøvd å komme med innspill om hvorfor vi har begrensninger og bidra til et balansert syn på saken. Vi har hele tiden hatt god kommunikasjon med helsemyndighetene. Vi jobber for å åpne opp, men må samtidig ta det nødvendige ansvaret innen smittevernreglene som gjelder. Jeg kan ikke bare ta med meg inntrykkene fra en stor intensivavdeling i unntakstilstand og si: Nå stopper vi med idrett, dere.

«Toppidretten rammes også når alt i samfunnet dreier seg om liv og helse»

- Hvem er det viktigst å komme i gang for? 
- Det vi først og fremst må passe på, er å tilrettelegge for god aktivitet for barn og unge. De fikk i særlig grad snudd livene på hodet. Det handler om å se mulighetene, innen rimelighetens grenser og innen smittevernreglene.

- Hva med de som lever av idretten?

- Det har vært en spesiell tid for de som driver med toppidrett. Jeg tror nok mange har følt på at det de driver med, jobben deres, plutselig ikke er så viktig. Toppidretten rammes også når alt i samfunnet dreier seg om liv og helse. Jeg har vært i noen dilemmaer, men jeg er ikke i tvil om idrettens rolle og viktighet også i tiden fremover. Jeg håper alle våre flotte idrettsutøvere klarer å holde motivasjonen oppe og er klare for å konkurrere og underholde oss igjen når tiden er inne for det.

- I mars var det kanskje mange som følte at jobben ikke var så viktig?

- Her på intensivavdelingen jobber vi med liv og død til vanlig, så for oss var kanskje ikke forskjellen så stor. Livet går videre utenfor intensivavdelingen hver eneste dag.

Når arbeidstiden er over, reiser hun hjem til samboeren på Høvik, hvis de ikke skal videre til hytta ved sjøen.

- Trener du kunstløp?

- Nei, det blir det lite av, svarer hun raskt. Jeg skulle vise noen tantebarn en piruett, og det gikk ganske dårlig. Jeg liker å trene ute. Sykle, løpe og gå på ski. Alt det vanlige.

Hun er også kjent for å lage god mat til venner og har et gjestfritt hjem.

- Du er flink til å arrangere morsomme selskap, sies det.

- Jeg har morsomme venner, så da blir det morsomme fester.

- Nå er det ikke så lett å samles?

- Det er på hold, ja. Jeg ble nylig femti, så kanskje sekstiårsdagen kan bli en feiring av at koronaviruset er over, sier hun litt spøkefullt.

Publisert: 8. oktober 2020. Tidsskr Nor Legeforen. DOI: 10.4045/tidsskr.20.0643

(C) Tidsskrift for Den norske legeforening 2023. Lastet ned fra tidsskriftet.no 26. april 2023. 